Summer 2016

\title{
Epilepsy Pipeline Conference Summary
}

Daniel J. Abrams, MD

CEO of Cerebral Therapeutics, LLC

Follow this and additional works at: https://jdc.jefferson.edu/jhnj

\section{Let us know how access to this document benefits you}

\section{Recommended Citation}

Abrams, MD, Daniel J. (2016) "Epilepsy Pipeline Conference Summary," JHN Journal: Vol. 11 : Iss. 2 , Article 6.

DOI: https://doi.org/10.29046/JHNJ.011.2.006

Available at: https://jdc.jefferson.edu/jhnj/vol11/iss2/6

This Article is brought to you for free and open access by the Jefferson Digital Commons. The Jefferson Digital Commons is a service of Thomas Jefferson University's Center for Teaching and Learning (CTL). The Commons is a showcase for Jefferson books and journals, peer-reviewed scholarly publications, unique historical collections from the University archives, and teaching tools. The Jefferson Digital Commons allows researchers and interested readers anywhere in the world to learn about and keep up to date with Jefferson scholarship. This article has been accepted for inclusion in JHN Journal by an authorized administrator of the Jefferson Digital Commons. For more information, please contact: JeffersonDigitalCommons@jefferson.edu. 


\section{Epilepsy Pipeline Conference Summary}

Daniel J. Abrams, MD

CEO of Cerebral Therapeutics, LLC

Each year the Epilepsy Therapy Project in conjunction with the Epilepsy Foundation puts on a conference for new development in diagnostics, device and medication therapies emerging in the field of epilepsy. We summarize below a few of the presentations that we thought would be of interest to the JHN readership. For a full listing of the presentations please see http://www.epilepsy.com/ accelerating-new-therapies/2016-epilepsy-pipeline-conference.

In the new mechanism of action therapies there were three new products that were presented. Scotts Edwards updated the conference on progress of the compound SF0034 which a potent and selective KCNQ2/3 activator designed to suppress neuronal hyperexcitability in patients with partial-onset epilepsy. SF0034 was found to have significantly greater potency and selectivity in preclinical models of epilepsy compared with the known product ritagabine. Tansna President Mark Robbins, presented progress fir a new novel non-sedating agent derived from propofol which in early work had a favorable efficacy and side effect profile. Michael Ragowski presented on a new Inhaled treatment for refractory epilepsy, which is a prodrug of propofol, as a potential rescue for patients having seizures and want to try and avoid the oncoming seizure. Lastly and for a similar target, Jackie French presented data on Phase 2a for a status epileptic rescue medication that being developed by Alexza Pharmaceuticals for patients who have repetitive seizures and want to stop after the first seizure.

On the diagnostic side, Rosalind Picard from MIT an affective computing expert, presented Empatica's increasing experience with epilepsy watch data primarily for patients generalized tonic clinic seizures. In the newcomer competition, several exciting new companies presented, Aswin Gunasekar the CEO of Zeto presented his companies new EEG device designed to make ambulatory EEG quicker, cheaper, more accurate, with less need for an EEG technician and potentially simplifying EEG review consultation by an off site Neurologist. The presentation consisted of having individuals try the prototype. It was clearly a significant improvement over what is available and generated a buzz amongst clinicians and early stage investors.

Regarding providing medical services side for epilepsy, EpiNightNurse an Internetbased system for nightly video and audio monitoring of patients with epilepsy was presented by Tamara and Joachim Coche, parents of a son with epilepsy from Scandinavia. The system consists of a real time video recording of a patient at night being viewed by specially trained epilepsy nurses in the Philippines who can then communicate back with caregivers. Essentially the Coche's created a business of a new system of care for epilepsy patients and monitoring and demonstrated how it works. Using time differences and technology they developed a method for an adjunctive way to monitor patients and it will be exciting to see how it grows and develops.

It is great for patients and physicians with epilepsy who are in need of new therapies that this annual conference occurs. We encourage you to attend and be involved if you can as the evolution and changes in the field are exciting to see first hand.

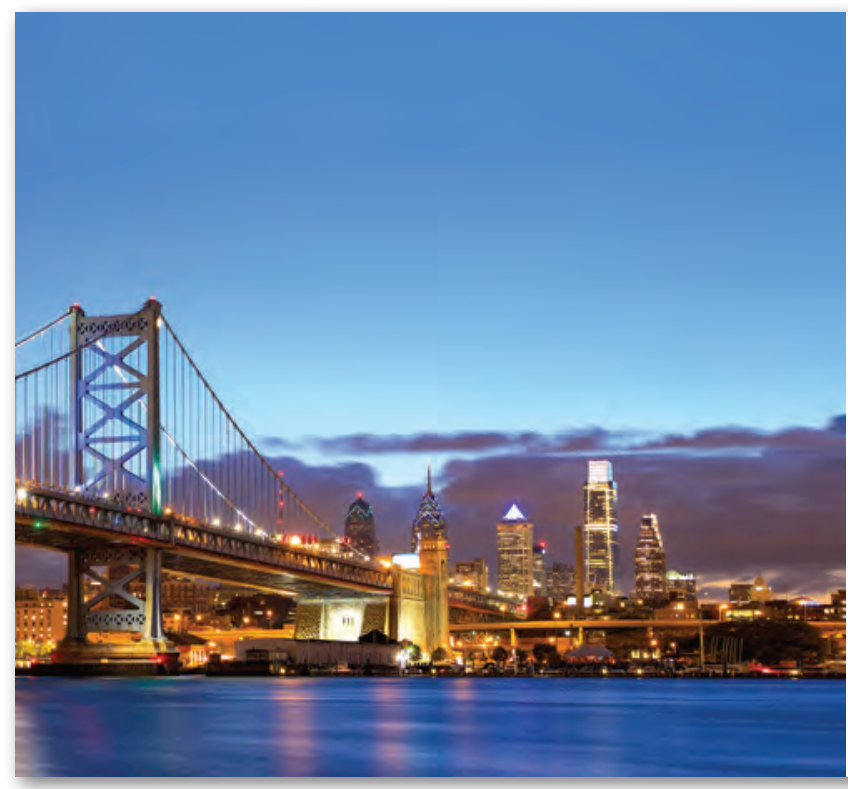

\section{sEEG and Epilepsy Surgery Symposium}

\section{October 21 and 22 | Philadelphia, PA}

Join a discussion for the latest trends and controversies in sEEG and epilepsysurgery. Topics include laser ablation, vagal nerve stimulation, responsive neurostimulation and an in-depth analysis of sEEG strategies. This is an accredited CME course designed for epilepsy neurosurgeons and epileptologists.

To register: WillsEye.org/continuing-medical-education 